\title{
SISTEM PENCATATAN SURAT MASUK DAN SURAT KELUAR PADA KANTOR KECAMATAN DUMAI SELATAN MENGGUNAKAN PEMROGRAMAN PHP
}

\author{
Yuzella Sandra ${ }^{1}$, Fitri Pratiwi ${ }^{2}$, Teuku Radillah ${ }^{3}$ \\ ${ }^{1,2,3}$ Sekolah Tinggi Manajemen Informatika dan Komputer (STMIK) Dumai \\ JL. Utama Karya Kel. Bukit Batrem Kec. Dumai Timur, Dumai-Riau 28811 \\ e-mail :yuzellasandra@gmail.com ${ }^{1}$
}

\begin{abstract}
ABSTRAK
Surat adalah sarana komunikasi untuk menyampaikan informasi atau suatu pernyataan secara tertulis kepada pihak lain, baik atas nama sendiri, jabatan yang disandang dari suatu instansi perusahaan atau organisasi. Telah dilakukan Penelitian pada Kantor Kecamatan Dumai Selatan, dimana terdapat permasalahan yaitu pencatatan data surat masuk maupun surat keluar yang hanya dicatat pada buku agenda. Maka dirancang sebuah Sistem Pencatatan Surat Masuk dan Surat Keluar Pada Kantor Camat Dumai Selatan Menggunakan Pemrograman PHP yang dapat membantu proses pencatatan dan pencarian berkas surat dengan cepat dan mudah, penyimpanan data surat lebih aman dan terhindar dari kerusakan dan kehilangan berkas surat, dan memberi kemudahan dalam membuat laporan data surat pada Kantor Kecamatan Dumai Selatan.
\end{abstract}

Kata kunci : sistem pencatatan, surat masuk, surat keluar, PHP

\section{PENDAHULUAN}

Kantor Kecamatan Dumai Selatan adalah salah satu instansi pemerintahan yang bergerak di bidang pelayanan dan di dalamnya tidak terlepas dari salah satu kegiatan yaitu pencatatan surat masuk dan surat keluar. surat adalah sarana komunikasi untuk menyampaikan informasi atau suatu pernyataan secara tertulis kepada pihak lain, baik atas nama sendiri, jabatan yang disandang dari suatu instansi perusahaan atau organisasi. (Rahmah, 2014). Dalam suatu organisasi baik swasta maupun pemerintahan kegiatan pencatatan surat sangatlah penting, karena isi dari surat pada instansi akan menjadi sarana pencapaian dari tujuan instansi tersebut, maka dari itu kegiatan pencatatan surat masuk dan surat keluar harus mendapatkan perhatian yang serius untuk dapat menunjang perkembangan perusahaan atau instansi pemerintah dari sisi administrasi.

Dalam proses pencatatan data surat masuk dan surat keluar pada Kantor Kecamatan Dumai Selatan masih dilakukan secara manual dengan menggunakan pulpen dan buku agenda. Pencatatan data surat masuk maupun surat keluar yang hanya dicatat pada buku agenda kemungkinan dapat terjadi redudansi data terhadap sistem pencatatan surat, membutuhkan waktu yang cukup lama untuk mencari berkas surat, penyimpanan dokumen hardcopy dapat memungkinkan terjadinya kerusakan dan kehilangan berkas surat, serta sulitnya dalam membuat laporan data surat.

Oleh karena itu dibutuhkan sebuah solusi sistem pencatatan surat secara digitalisasi untuk dapat membantu proses pencatatan dan pencarian berkas surat dengan cepat, penyimpanan data surat lebih aman dan terhindar dari kerusakan dan kehilangan berkas surat, dan memberi kemudahan dalam membuat laporan data surat pada Kantor Kecamatan Dumai Selatan.

Dari latar belakang diatas maka perlu menentukan tujuan penelitian agar dapat memberikan kejelasan dalam penelitian.

Adapun tujuan dari penelitian ini adalah :

1. Merancang sistem pencatatan surat masuk dan surat keluar menggunakan PHP untuk mempermudah proses pencatatan surat.

2. Menghindari terjadinya kerusakan dan kehilangan berkas surat.

3. Agar tidak adanya redudansi data pada pencatatan surat masuk dan surat keluar. 
I N F O R M A T I K A

Jurnal Informatika, Manajemen dan Komputer, Vol. 9 No. 1, Mei 2017

eISSN : 2580-3042

pISSN : 1979-0694

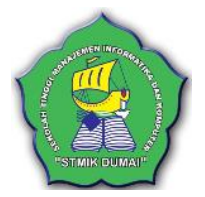

\section{a. Sistem}

System adalah sekelompok elemen yang saling berhubungan atau berinteraksi hingga membentuk satu persatuan. Konsep umum sistem adalah sekelompok komponen yang saling berhubungan, bekerjasama untuk mencapai tujuan bersama dengan menerima input serta mengasilkan output dalam proses transformasi yang teratur. (Indrajani, 2015)

\section{b. Informasi}

Informasi adalah data yang telah diklasifikasi atau diolah atau diinterprestasi untuk digunakan dalam proses pengambilan keputusan. Sistem pengolahan mengolah data menjadi informasi atau tepatnya mengolah data dari bentuk tak berguna menjadi berguna bagi yang menerimanya. (Sutabri, 2012)

\section{c. Surat}

Surat adalah sarana komunikasi untuk menyampaikan informasi atau suatu pernyataan secara tertulis dari suatu pihak kepada pihak lain, baik atas nama sendiri, jabatan yang disandang dari suatu instansi perusahaan atau organisasi. (Rahmah, 2014)

\section{d. Surat Masuk}

Surat masuk merupakan semua surat yang dialamatkan, ditujukan dan diterima oleh organisasi, perusahaan atau instansi, baik yang berasal dari perorangan maupun dari suatu organisasi perusahaan instansi dan lainnya. (Prawono \& Pamungkas, 2015)

\section{e. Surat Keluar}

Surat keluar adalah surat yang dibuat oleh instansi atau perusahaan yang ditujukan kepada instansi atau perusahaan lain atau untuk kepentingan internal. (Prawono \& Pamungkas, 2015)

\section{f. Personel Home Page (PHP)}

PHP adalah singkatan dari "Hypertext Preprocessor", yang merupakan sebuah bahasa scripting yang terpasang pada HTML untuk membuat webside yang dinamis. PHP merupakan server side scripting yaitu sintak dan perintahperintah PHP akan dieksekusi deserver kemudian hasilnya baru ditampilkan ke browser dalam format HTML. (Dahlan, 2013)

PHP merupakan bahasa berbentuk script yang ditempatkan didalam server baru kemudian diproses. Kemudian hasil pemrosesan dikirim kepada web browser klien. Bahasa pemrograman ini dirancang khusus untuk membentuk web dinamis. Artinya, pemrograman PHP dapat membentuk suatu tampilan berdasarkan permintaan terkini, misalnya halaman yang menampilkan daftar tamu. (Nur Rubiati, 2018)

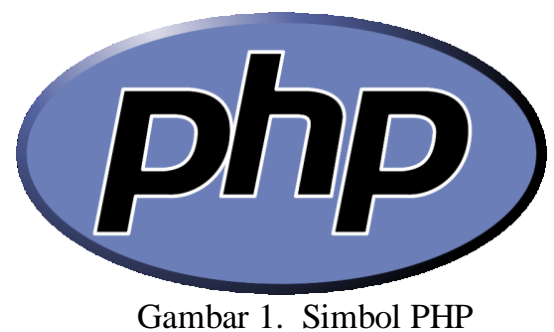

Sumber : (Noor, 2016)

\section{g. $X \mathbf{A M P P}$}

$X A M P$ merupakan dari singkatan dari $\mathrm{X}$ (empat sistem operasi apapun), Apache, MySQL, PHP, dan Perl. XAMPP adalah tool yang menyediakan paket perangkat lunak dalam satu buah paket. Dalam paket XAMPP sudah terdapat Apache (web server), MySQL (database), PHP (server side scripting), Perl, FTP server, PhpMyAdmin dan berbagai pustaka bantu lainnya.(Andi Offset, 2014)

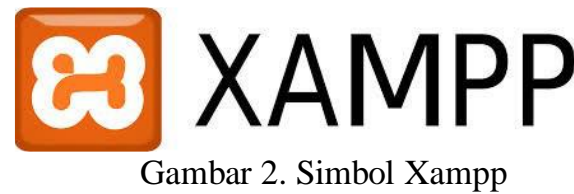

Sumber : (Noor, 2016)

h. $M y S Q L$

MySQL merupakan turunan salah satu konsep utama dalam basis data yang telah ada sebelumnya; SQL (Structured Query Language). SQL adalah sebuah konsep pengoperasian basis data, terutama untuk pemilihan atau seleksi dan pemasukan data yang memungkinkan pengoperasian data dikerjakan dengan mudah secara otomatis. (Priyanti \& Iriani, 2013)

\section{METODOLOGI PENELITIAN}

Adapun metodologi yang digunakan dalam penelitian ini adalah metode waterfall yang berisikan kerangka kerja yang dilakukan guna untuk menyelesaikan permasalahan, yaitu sebagai berikut :

Model ini melakukan pendekatan secara sistematis dan urut mulai dari level kebutuhan sistem lalu menuju ke tahap analisis, desain, coding, testing / verification, dan maintenance. Disebut dengan waterfall karena tahap demi tahap yang dilalui harus menunggu selesainya 
I N F ORM A T I K

Jurnal Informatika, Manajemen dan Komputer, Vol. 9 No. 1, Mei 2017

eISSN : 2580-3042

pISSN : 1979-0694

tahap sebelumnya dan berjalan berurutan. (Pascapraharastyan, Supriyanto, \& Sudarmaningtyas, 2014)

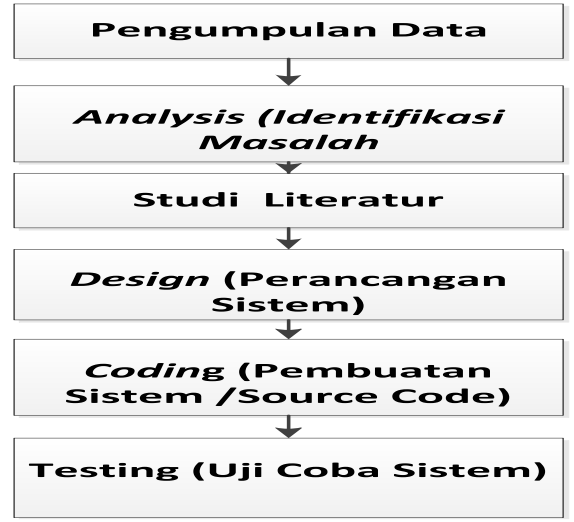

Gambar 3. Kerangka Kerja Penelitian

Adapun penjelesan dari kerangka kerja pada metode penelitian diatas adalah sebagai berikut :

1. Pengumpulan data

Pada tahap ini dilakukan beberapa teknik yaitu :

a. Wawancara (interview)

Metode ini dilakukan untuk mengumpulkan data melalui proses tanya jawab dengan beberapa narasumber ditempat dimana objek penelitian dilakukan. Proses tanya jawab ini dilakukan langsung di Kantor Kecamatan Dumai Selatan.

b. Pengamatan (Observasi)

Pada metode ini dilakukan pengamatan langsung pada Kantor Kecamatan Dumai Selatan untuk mengumpulkan data yang merupakan sumber informasi yang sangat penting dan jelas yang dapat membantu dalam menganalisa dan selanjutnya dalam rangka pembangunan sistem yang sedang dibutuhkan.

2. Analysis (Analisa Masalah)

Mempelajari sistem yang ada dan menganalisis terhadap permasalahan untuk mengetahui kebutuhan serangkaian dan teknik yang diperlukan serta menemukan batasanbatasan sistem. Sehingga dapat menentukan cara yang paling efektif dalam menyelesaikan dan akan memberikan solusi yang diperlukan serta manfaat yang akan diperoleh.

3. Studi Literatur

Pada tahap ini dilakukan untuk pencarian data dengan membaca dan mempelajari berbagai buku-buku, internet serta pengetahuan yang berhubungan dengan masalah yang akan diteliti yaitu sistem pencatatan surat masuk dan surat keluar.

4. Design (Perancangan Sistem)

Merupakan tahapan analisis dalam kaitan mencari atau merumuskan alternatif-alternatif pemecahan masalah. Setelah menganalisis masalah, selanjutnya akan dilakukan perancangan sistem yang telah ditetapkan menggunakan Aliran Sistem Informasi (ASI), Context Diagram, Data Flow Diagram (DFD), Entity Relationship Diagram (ERD) dan Bagan Alir (Flowchart).

5. Coding (Pembuatan Sistem/Source Code)

Tahap pembuatan kode merupakan tahap dimana membuat source code yang diperlukan untuk sistem aplikasi pencatatan surat dari perancangan yang telah dibuat sebelumnya.

6. Testing (Uji Coba Sistem)

Proses uji coba yang dilakukan untuk mengetahui keberhasilan program yang kita buat, yang nantinya akan diimplementasikan berupa aplikasi program (software), guna mengetahui apakah sistem yang dibangun sudah layak untuk dioperasikan. Pada tahap ini terdapat dua metode testing yaitu dengan metode Black Box Testing dan White Box Testing.

a. Metode Black Box Testing

Metode Black Box Testing adalah metode yang berfokus pada spesifikasi fungsional dari perangkat lunak. Tester dapat mendefinisikan kumpulan kondisi input dan melakukan pengetesan pada spesifikasi fungsional program. (Mustaqbal, Firdaus, \& Rahmadi, 2015)

b. Metode White Box Testing

Metode Black Box Testing adalah salah satu cara untuk menguji suatu aplikasi atau software dengan cara melihat modul untuk dapat meneliti dan menganalisa kode dari program yang dibuat ada yang salah atau tidak. (Mustaqbal et al., 2015)

\section{HASIL DAN PEMBAHASAN}

Pada bagian hasil dan pembahasan ini terdapat beberapa bagian dari analisis dan perancangan sistem, diantaranya :

\section{a. Analisis Sistem (ASI Lama)}

Adapun analisis sistem (ASI Lama) dari penelitian ini adalah sebagai berikut : 
I N F ORM A T I K

Jurnal Informatika, Manajemen dan Komputer, Vol. 9 No. 1, Mei 2017

eISSN : 2580-3042

pISSN : 1979-0694

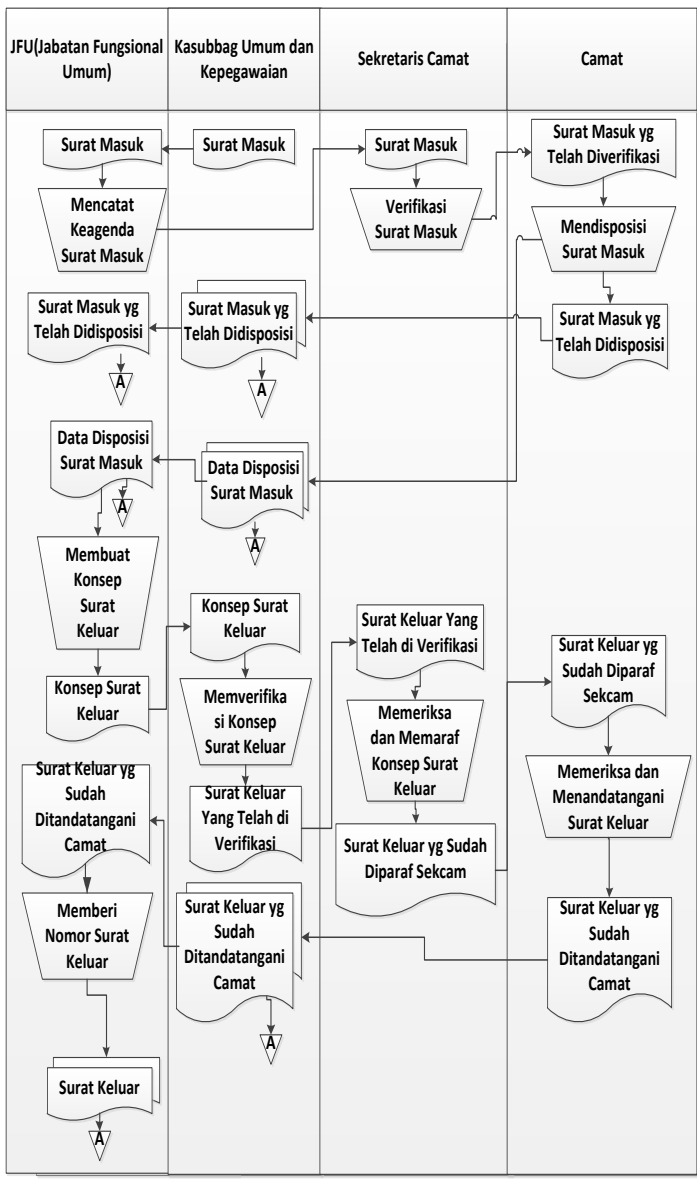

Gambar 4. Analisa Sistem Informasi Yang Sedang Berjalan (ASI Lama)

Adapun penjelasan dari gambar Analisa Sistem Informasi (ASI) yang sedang berjalan yaitu :

1. Surat masuk yang diterima Kasubbag Umum dan Kepegawaian diberikan kepada JFU untuk dicatat ke buku agenda surat masuk. Setelah surat masuk di catat lalu diberikan kepada Sekcam untuk diverifikasi.

2. Surat masuk yang telah diverifikasi Sekcam di berikan ke Camat untuk didisposisikan. Surat Masuk yang telah didisposisikan Camat diberikan kepada Kasubbag Umum dan Kepegawaian dibuat dua rangkap untuk diarsipkan oleh Kasubbag Umum dan JFU. Data disposisi surat masuk juga dibuat 2 rangkap oleh Kasubbag Umum dan Kepegawaian untuk diarsipkan di Kasubbag Umum dan JFU.

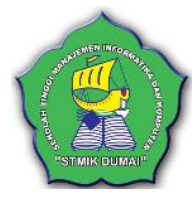

3. Lalu JFU membuat konsep surat keluar dan memberikan konsep surat keluar kepada Kasubbag Umum untuk diverifikasi. Setelah Surat di verifikasi, selanjutnya surat diberi kepada Sekcam untuk diperiksa kembali dan diparaf.

4. Surat yang sudah diparaf Sekcam di berikan kepada Camat untuk di periksa kembali dan ditanda tangani

5. Setelah surat di tandatangani Camat lalu diserahkan kembali ke Kasubbag Umum dan dibuat dua rangkap, satu diarsipkan Kasubbag dan satu diberikan kepada JFU untuk diberi nomor surat. Surat yang telah di beri nomor lalu di buat dua rangkap, satu untuk diarsipkan JFU, dan satu lagi untuk dikirim ke alamat tujuan surat.

b. Analisis Kebutuhan Sistem (ASI Baru)

Adapun analisis kebutuhan (ASI Baru) dari sistem ini adalah sebagai berikut :

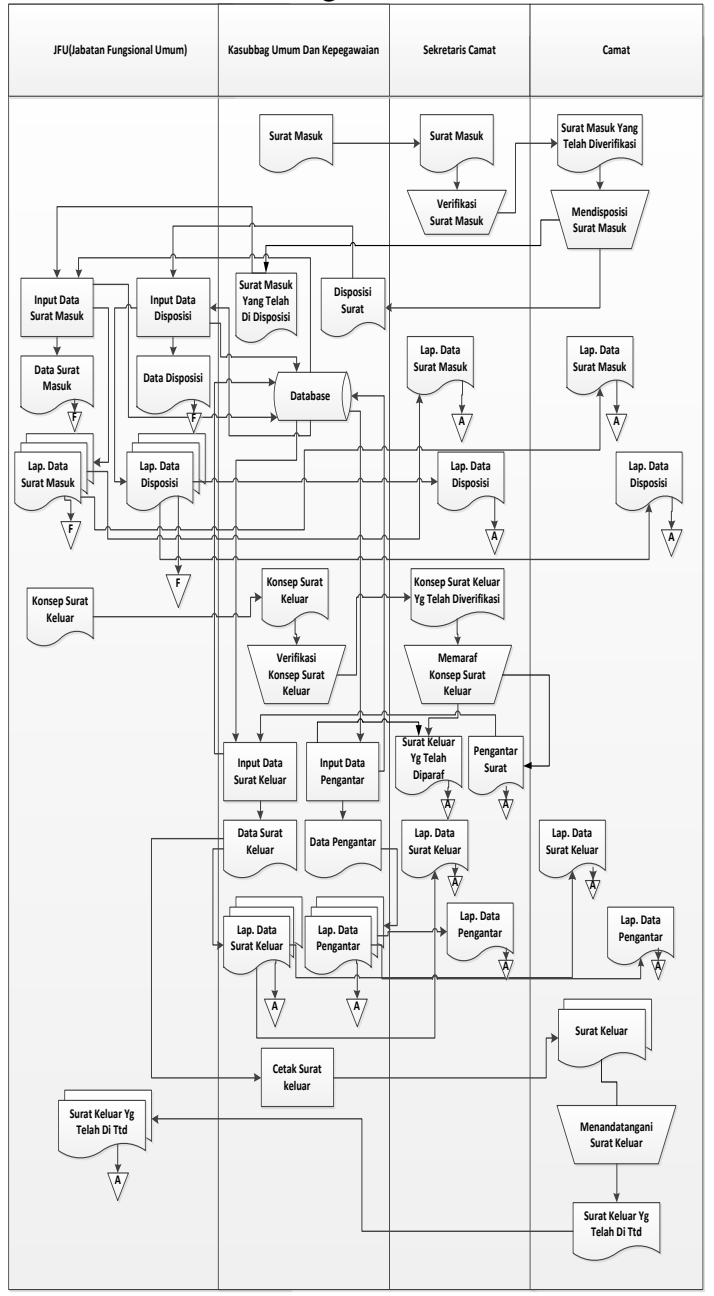

Gambar 5. Aliran Sistem Informasi Baru (ASI Baru) 
I N F O R M A T I K A

Jurnal Informatika, Manajemen dan Komputer, Vol. 9 No. 1, Mei 2017

eISSN : 2580-3042

pISSN : 1979-0694

Adapun penjelasan dari gambar Analisa

Sistem Informasi (ASI) yang baru yaitu :

1. Kasubbag Umum dan Kepegawaian memberikan surat kepada Sekcam untuk diverifikasi. Lalu Sekcam memberikan surat masuk yang telah diverifikasi kepada Camat untuk di disposisikan.

2. Setelah surat masuk di disposisikan oleh Camat, surat dikembalikan ke Kasubbag Umum dan Kasubbag Umum memberikan surat kepada JFU untuk menginputkan data surat masuk dan data disposisi.

3. JFU menginputkan surat masuk dan disposisi ke sistem dan tersimpan ke database. Data yang diinputkan tadi menjadi data surat masuk dan data disposisi dan masing-masing diarsipkan dalam bentuk file.

4. Data surat masuk dan data disposisi yang telah diinputkan menghasilkan laporan surat masuk dan laporan disposisi yang dibuat 3 rangkap untuk diarsipkan JFU, Sekcam, dan Camat dalam bentuk file.

5. JFU membuat konsep surat keluar, lalu konsep diberikan kepada Kasubbag Umum untuk diverifikasi. Setelah konsep surat dan lembar pengantar di verifikasi diberikan kepada Sekcam untuk diparaf, lalu surat dan pengantar yang telah diparaf diberikan kembali kepada Kasubbag Umum untuk di inputkan ke sistem. Surat keluar dan pengantar yang sudah diinputkan menjadi data surat keluar dan data pengantar dan menghasilkan laporan data surat keluar dan laporan data pengantar yang dibuat 3 rangkap untuk diarsipkan Kasubbag Umum, Sekcam, dan Camat dalam bentuk dokumen arsip.

6. Data surat keluar di cetak dan diberikan kepada camat untuk di tandatangani.setelah surat ditandatangani lalu diberikan kepada JFU dan dibuat 2 rangkap untuk diarsipkan dan dikirim ke instansi tujuan.

\section{c. Context Diagram}

Context diagram adalah aliran sistem secara keseluruhan. Adapun Context Diagram pada penelitian ini adalah :

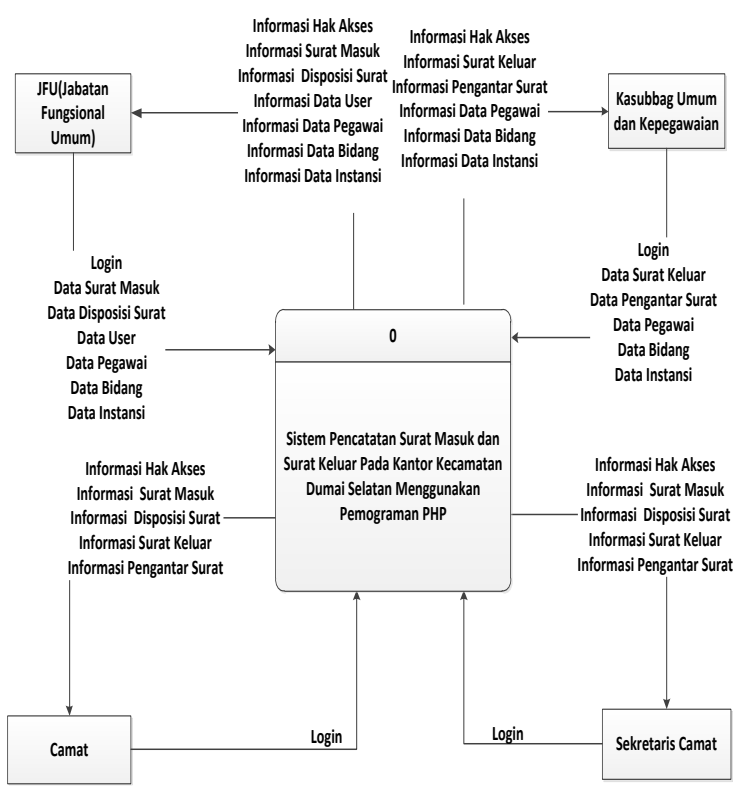

Gambar 6. Context Diagram

\section{d. Data Flow Diagaram (DFD)}

Adapun DFD pada penelitian ini adalah sebagai berikut :

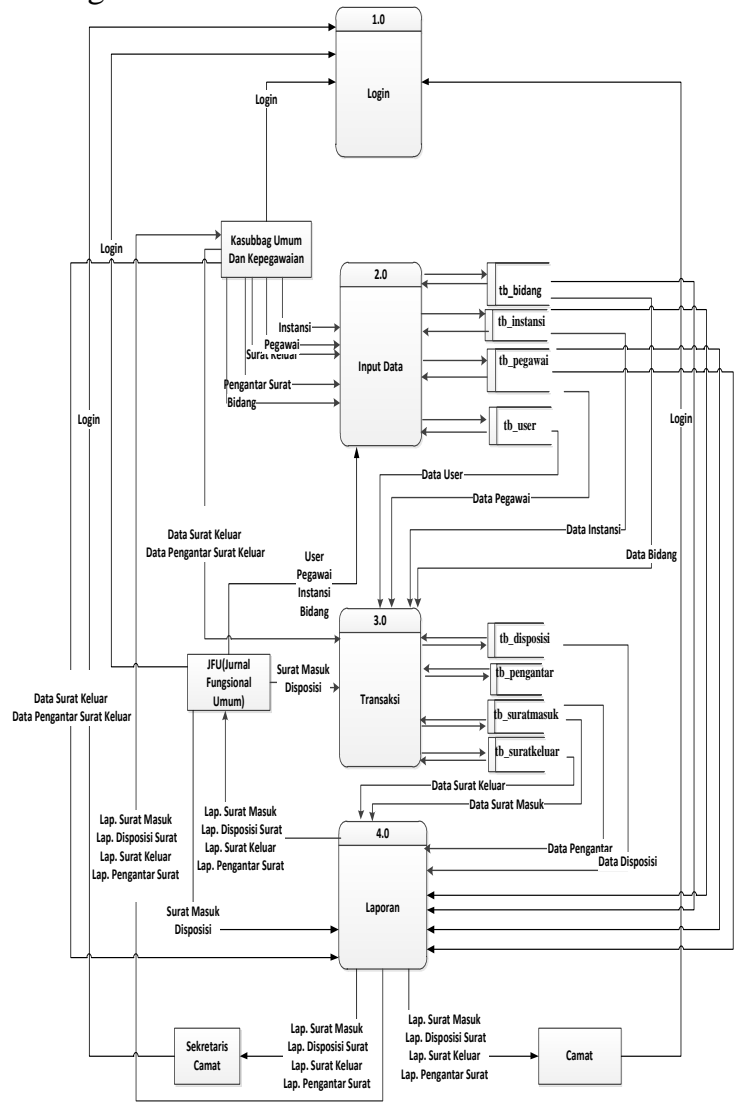

Gambar 7. Data Flow Diagram (DFD) 
IN F O R M A T I A

Jurnal Informatika, Manajemen dan Komputer, Vol. 9 No. 1, Mei 2017

elSSN : 2580-3042

pISSN : 1979-0694

\section{e. Entity Relationship Diagram (ERD)}

Adapun Entity Relationship Diagram (ERD) pada pemodelan data penelitian ini adalah sebagai berikut :

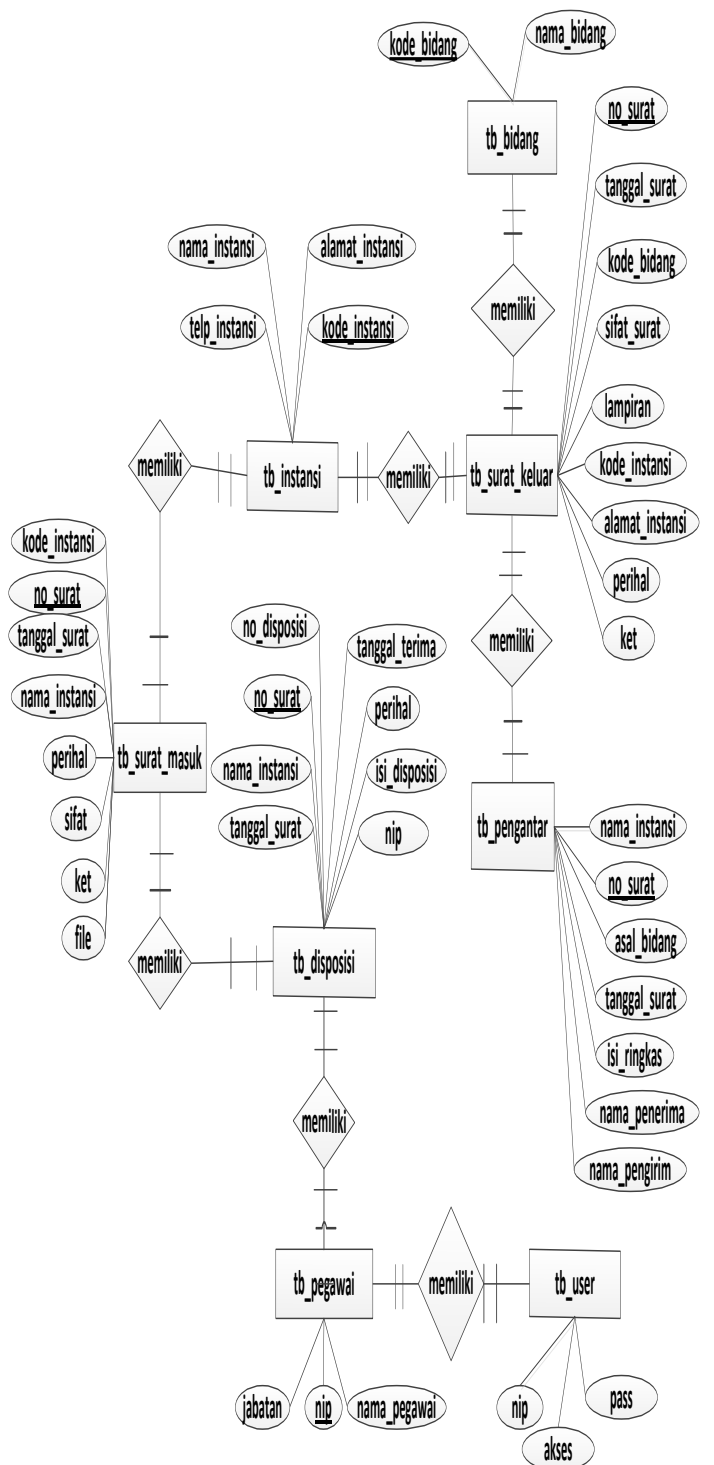

Gambar 8. Entity Relationship Diagram (ERD)

\section{f. HIPO (Struktur Program)}

HIPO adalah struktur program dari sistem. Adapun HIPO (Struktur Program) pada penelitian ini adalah sebagai berikut :
1. HIPO JFU (Jurnal Fungsional Umum)

Dibawah ini adalah tampilan HIPO untuk bagian JFU (Jabatan Fungsional Umum), yaitu

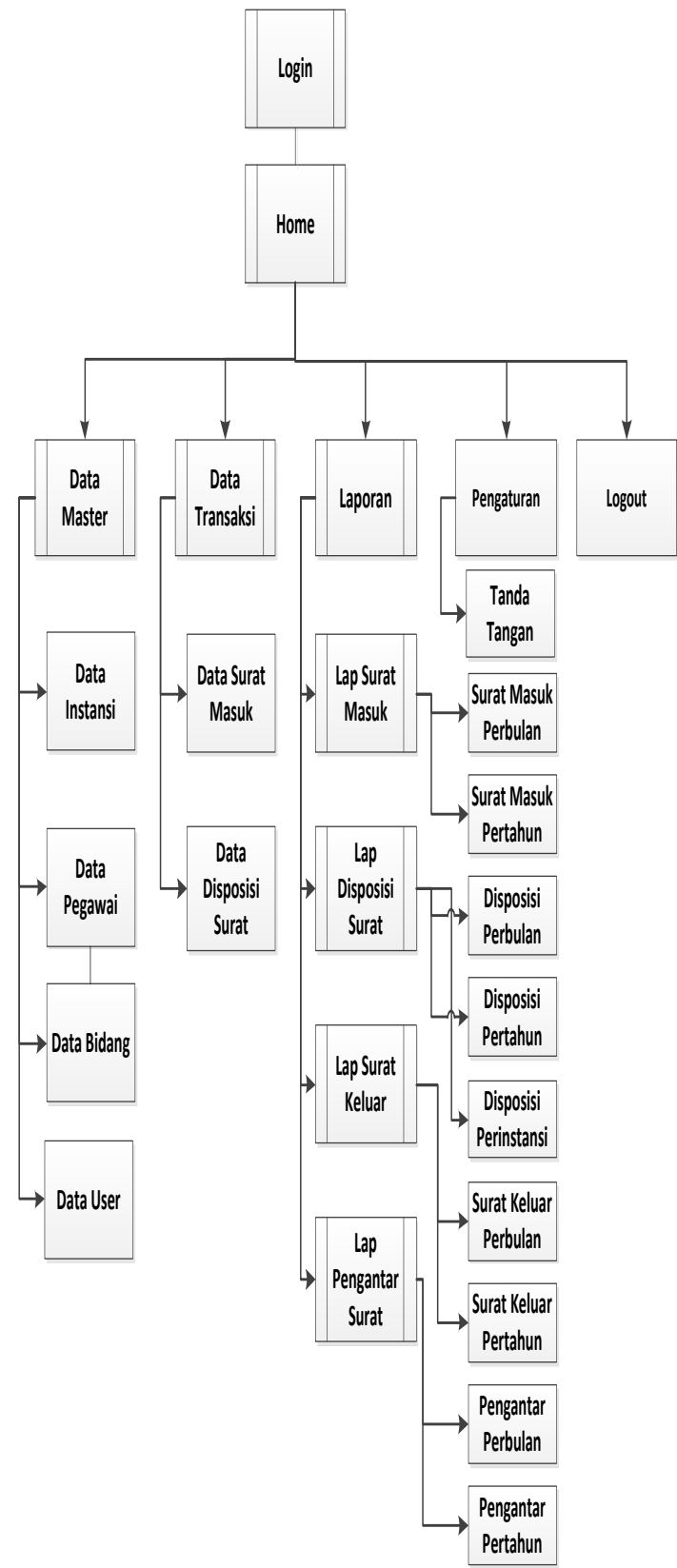

Gambar 9. Hierarchy Input Procses Output (HIPO) JFU 
IN F ORM A I K A

Jurnal Informatika, Manajemen dan Komputer, Vol. 9 No. 1, Mei 2017

elSSN : 2580-3042

pISSN : 1979-0694

2. HIPO Kasubbag Umum dan Kepegawaian Dibawah ini adalah tampilan HIPO untuk bagian Kasubbag Umum dan Kepegawaian yaitu :

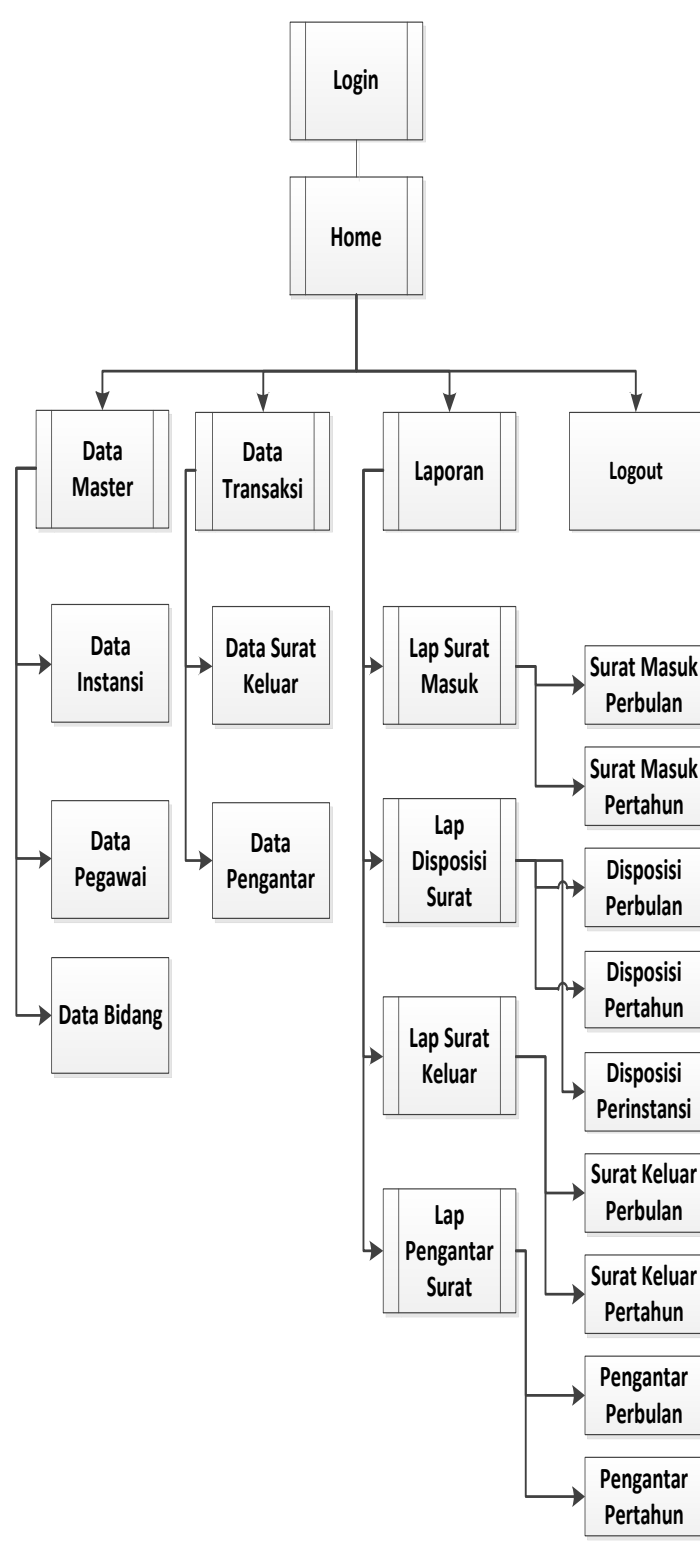

Gambar 10. Hierarchy Input Procses Output (HIPO) Kasubbag Umum dan Kepegawaian

3. HIPO Sekretaris Camat

Dibawah ini adalah tampilan HIPO untuk bagian Sekretaris Camat, yaitu :

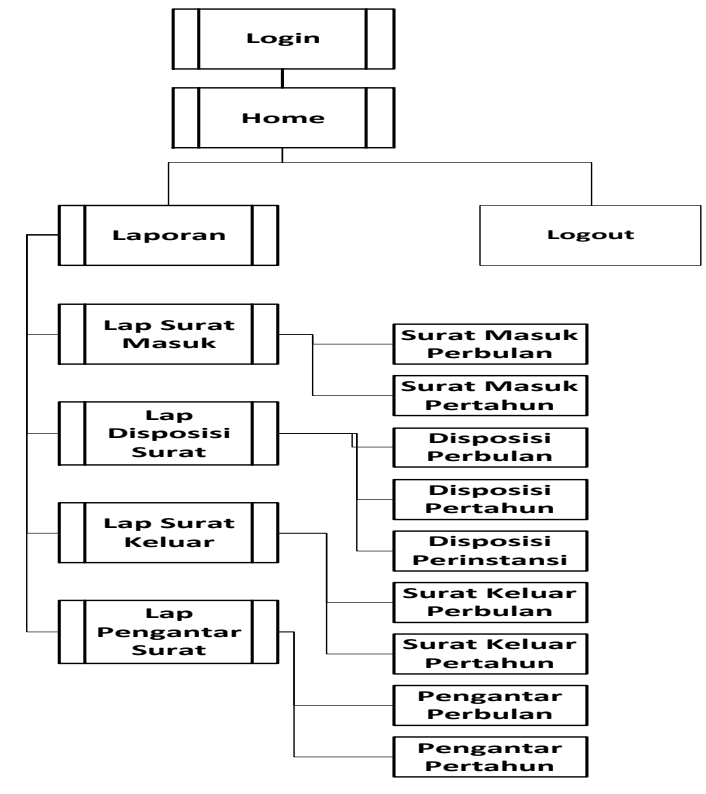

Gambar 11. Hierarchy Input Procses Output (HIPO) Sekretaris Camat

\section{HIPO Camat}

Dibawah ini adalah tampilan HIPO untuk Camat, yaitu :

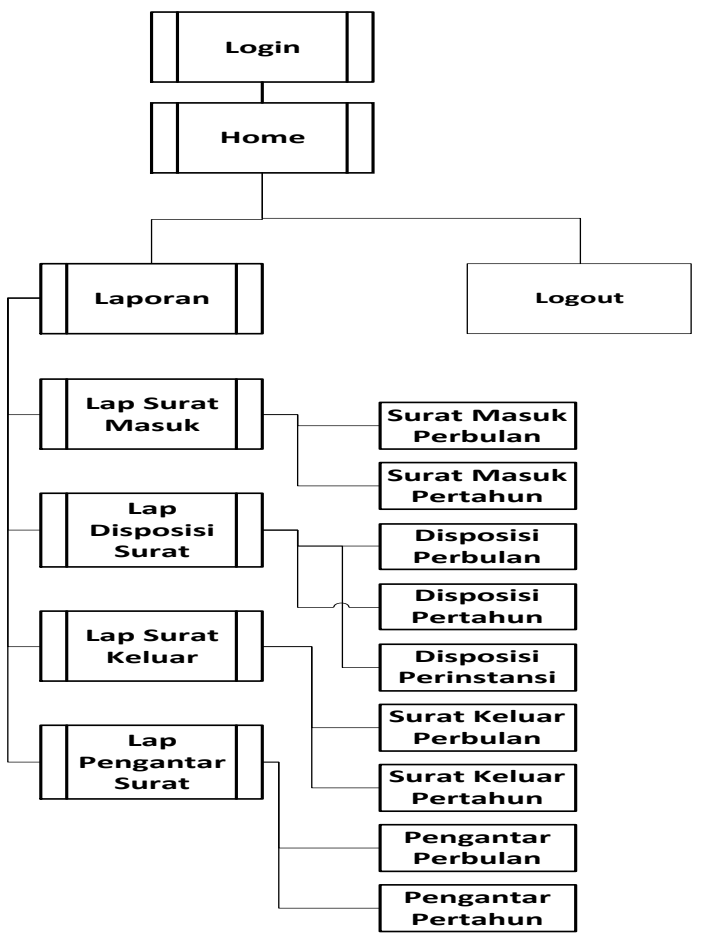

Gambar 12. Hierarchy Input Procses Output (HIPO) Camat 
I N F ORM A T I K

Jurnal Informatika, Manajemen dan Komputer, Vol. 9 No. 1, Mei 2017

eISSN : 2580-3042

pISSN : 1979-0694

\section{g. Implementasi Sistem}

1. Tampilan Login

Adapun halaman login Aplikasi surat ini adalah sebagai berikut :

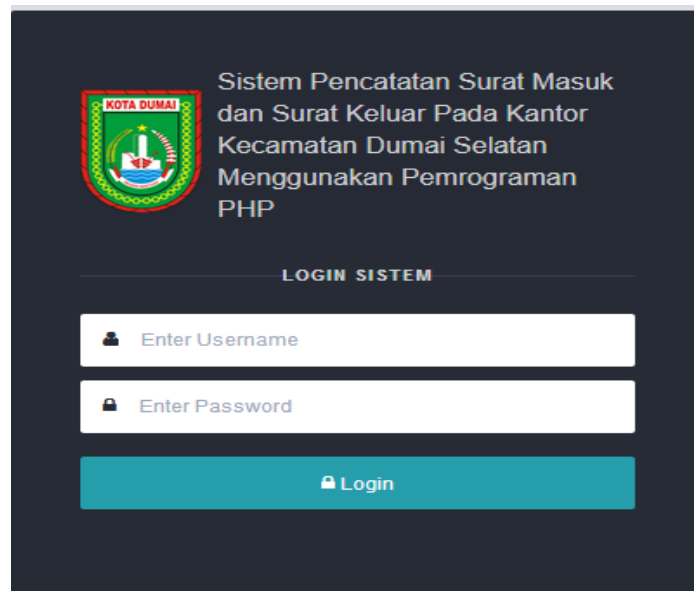

Gambar 13. Tampilan Form Login Aplikasi Surat

Pada tampilan login sistem terdapat 4 hak akses untuk user, yaitu hak akses sebagai JFU (Jabatan Fungsional umum), Kasubbag Umum dan Kepegawaian, Sekretaris Camat, dan Camat.

2. Tampilan Menu Utama

Adapun tampilan menu utama untuk JFU (Jabatan Fungsional Umum) adalah seperti gambar di bawah ini :

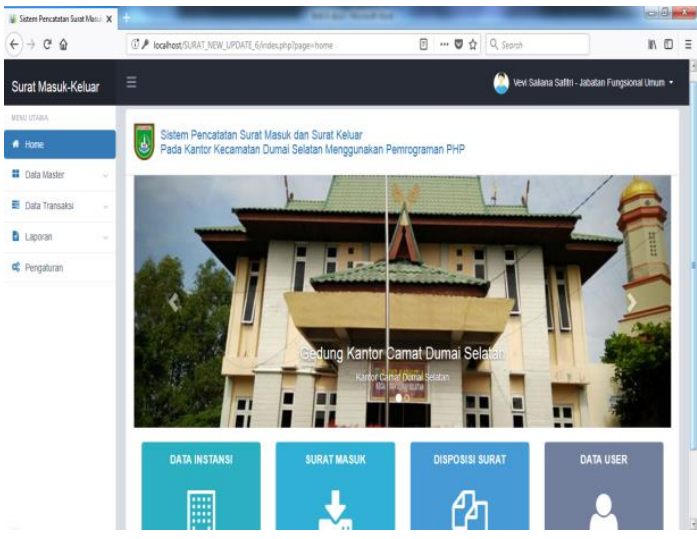

Gambar 14. Tampilan Menu Utama JFU

3. Tampilan Input Data Master

a. Input Data Instansi

Adapun tampilan input data instansi adalah sebagai berikut :
FE Data Master Data Instansi

DATA IN STANSI

Kode Instansi

IS0041

Nama Instansi

Nama Instansi

Alamat Instans

Alamat Instansi

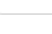

No Telp

No Telp

E Simpan \& Batal

Gambar 15. Tampilan Input Data Instansi

Pada tampilan ini user wajib mengisi kode instansi, nama instansi, alamat instansi, dan no. telepon secara lengkap lalu mengklik tombol simpan untuk menyimpan data.

b. Input Data Pegawai

Adapun tampilan input data pegawai adalah sebagai berikut :

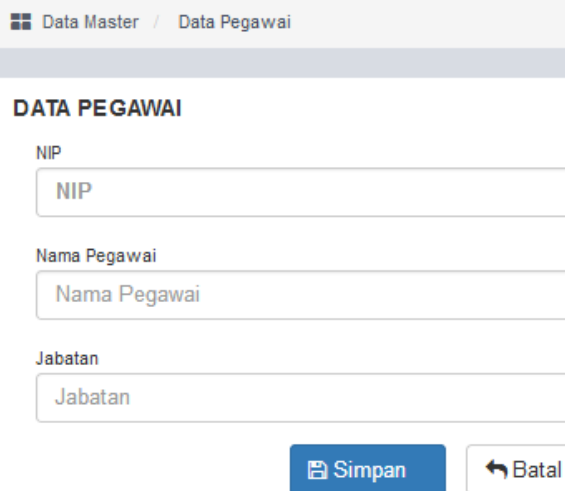

Gambar 16. Tampilan Input Data Pegawai

Pada tampilan ini user wajib mengisi NIP, nama pegawai, dan jabatan secara lengkap, dan mengklik tombol simpan untuk menyimpan data.

c. Input Data User

Adapun tampilan input data user adalah sebagai berikut : 
I N F ORM A T I K

Jurnal Informatika, Manajemen dan Komputer, Vol. 9 No. 1, Mei 2017

eISSN : 2580-3042

pISSN : 1979-0694

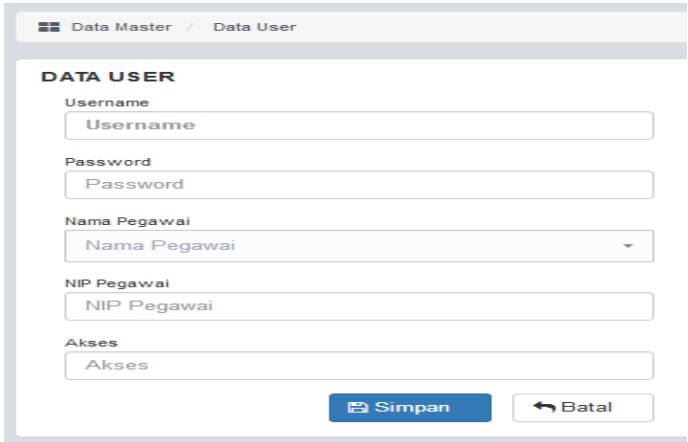

Gambar 17. Tampilan Input Data User

Pada tampilan ini user wajib mengisi username, password, nama pegawai, NIP pegawai, dan akses secara lengkap, dan mengklik tombol simpan untuk menyimpan data.

d. Input Data Bidang

Adapun tampilan input data bidang adalah sebagai berikut :

Et. Data Master / Data Bidang

DATA BIDANG

Kode Bidang

B0018

Nama Bidang

Nama Bidang

\section{Simpan}

↔Batal

Gambar 18. Tampilan Input Data Bidang

Pada tampilan ini user wajib mengisi kode bidang dan nama bidang secara lengkap, dan mengklik tombol simpan untuk menyimpan data.

4. Tampilan Input Data Transaksi

a. Input Data Surat Masuk

Adapun tampilan input data surat masuk adalah sebagai berikut :

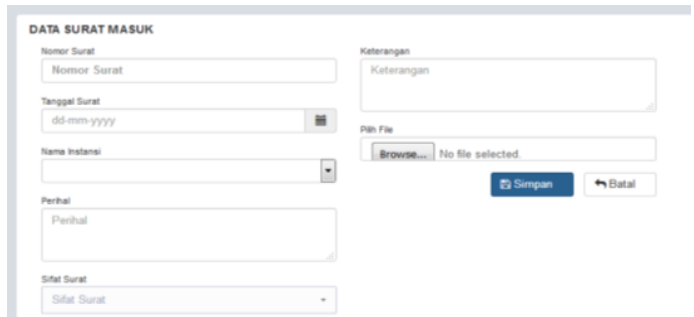

Gambar 19. Tampilan Input Data Surat Masuk
Pada tampilan ini user wajib mengisi nomor surat, tanggal surat, nama instansi, perihal, sifat surat dan keterangan secara lengkap, dan mengklik tombol simpan untuk menyimpan data.

b. Input Data Disposisi

Adapun tampilan input data disposisi adalah sebagai berikut :

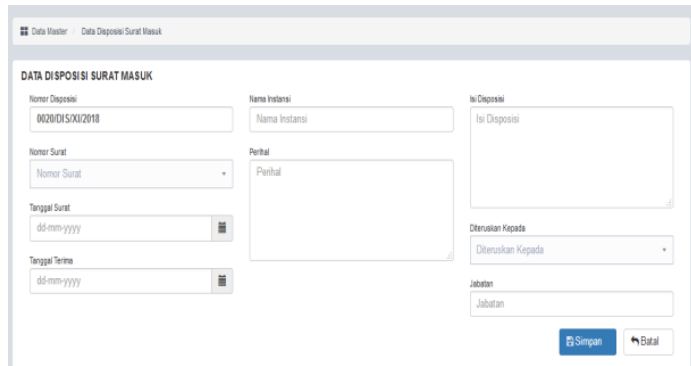

Gambar 20. Tampilan Input Data Disposisi

Pada tampilan ini user wajib mengisi kode nomor disposisi, nomor surat, tanggal surat, tanggal terima, nama instansi, perihal isi disposisi, diteruskan kepada, dan jabatan secara lengkap, dan mengklik tombol simpan untuk menyimpan data.

c. Input Data Surat Keluar

Adapun tampilan input data surat keluar adalah sebagai berikut :

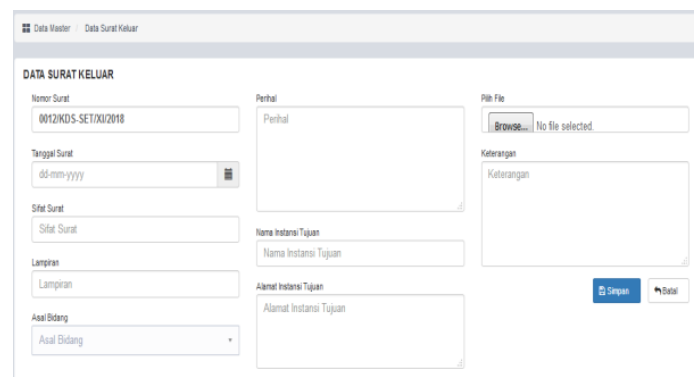

Gambar 21. Tampilan Input Data Surat Keluar

Pada tampilan ini user wajib mengisi nomor surat, tanggal surat, sifat surat, lampiran, asal bidang, perihal, nama instansi tujuan, alamat instansi tujuan dan keterangan secara lengkap, dan mengklik tombol simpan untuk menyimpan data.

d. Input Data Pengantar Surat

Adapun tampilan input data pengantar surat adalah sebagai berikut : 
INFORM T I K

Jurnal Informatika, Manajemen dan Komputer, Vol. 9 No. 1, Mei 2017

eISSN : 2580-3042

pISSN : 1979-0694

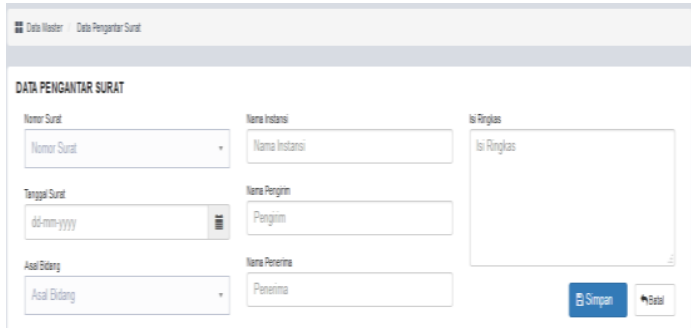

Gambar 22. Tampilan Input Data Pengantar Surat

Pada tampilan ini user wajib mengisi nomor surat, tanggal surat, asal bidang, nama instansi, nama pengirim, nama penerima dan isi ringkas secara lengkap, dan mengklik tombol simpan untuk menyimpan data.

5. Tampilan Laporan

a. Laporan Data Surat Masuk

Adapun tampilan laporan data surat masuk adalah sebagai berikut :

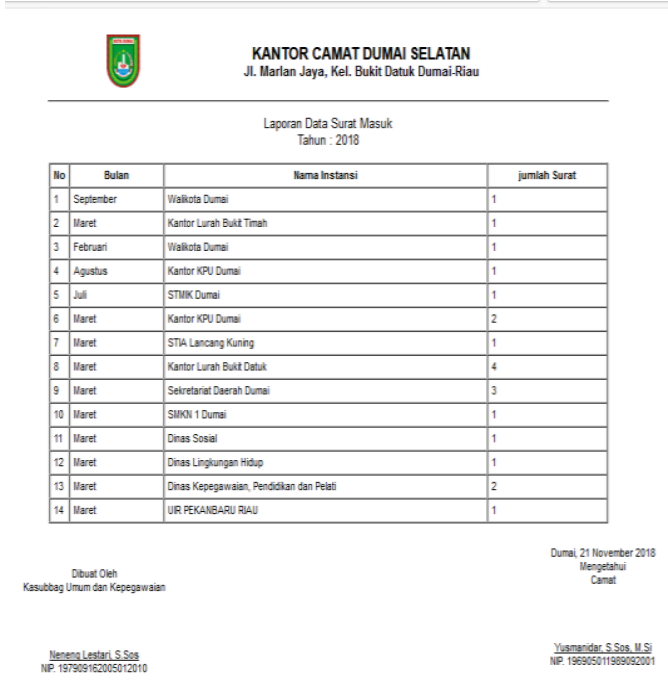

Gambar 23. Tampilan Laporan Data Surat Masuk

b. Laporan Data Disposisi

Adapun tampilan laporan data disposisi adalah sebagai berikut :

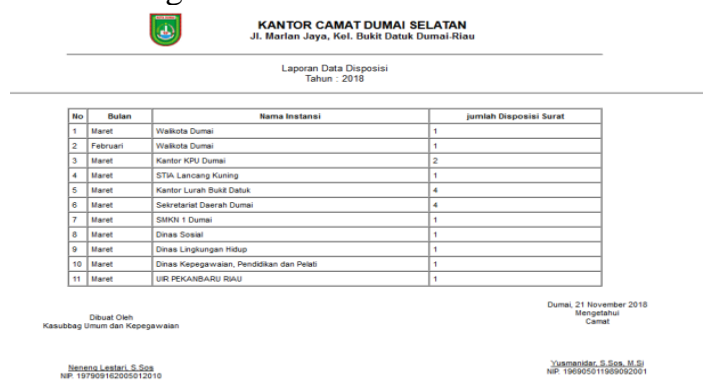

Gambar 24. Tampilan Laporan Data Disposisi c. Laporan Data Surat Keluar

Adapun tampilan laporan data surat keluar adalah sebagai berikut :

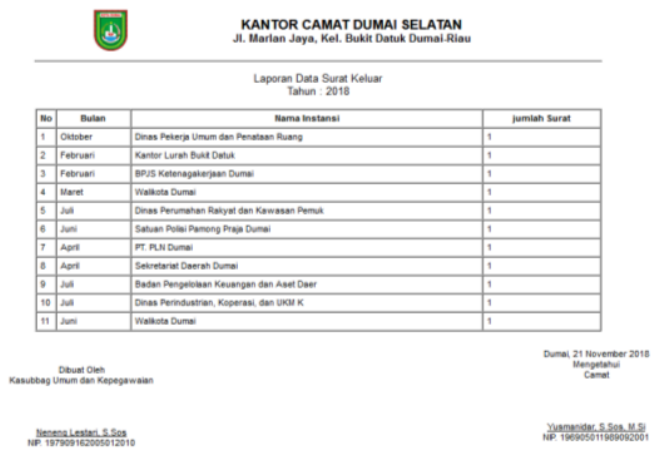

Gambar 25. Tampilan Laporan Data Surat Keluar

d. Laporan Data Pengantar Surat Adapun tampilan laporan data pengantar surat adalah sebagai berikut :

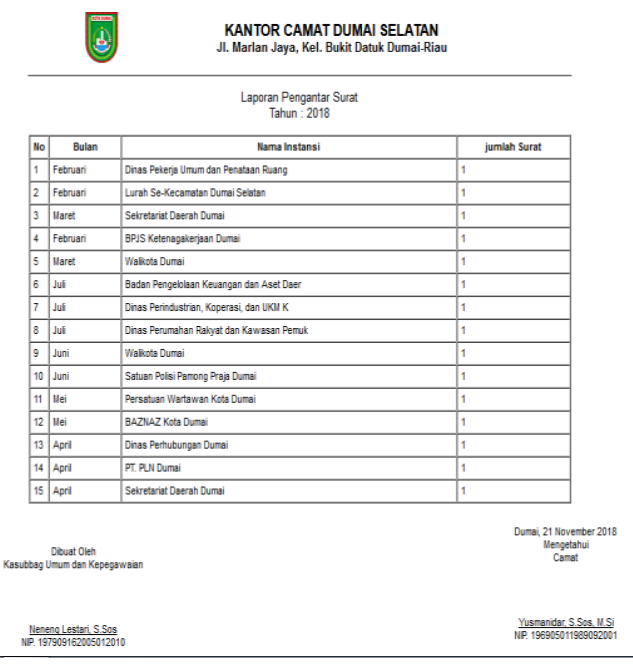

Gambar 26. Tampilan Laporan Data Pengantar Surat

\section{KESIMPULAN}

Berdasarkan hasil pembahasan yang telah diuraikan, dapat diambil kesimpulan sebagai berikut :

1. Dengan sistem ini dapat membantu karyawan melakukan proses pencarian data surat dengan cepat.

2. Dengan sistem ini penyimpanan data surat lebih aman dan terhindar dari kerusakan dan kehilangan berkas surats.

3. Dengan sistem ini memberi kemudahan karyawan dalam membuat laporan data surat. 
I N F ORM A T I K

Jurnal Informatika, Manajemen dan Komputer, Vol. 9 No. 1, Mei 2017

elSSN : 2580-3042

pISSN : 1979-0694

\section{REFERENSI}

Andi Offset. (2014). Panduan Aplikasi \& Solusi Sistem Informasi Penjualan Online Untuk Tugas Akhir. Yogyakarta: Wahana Komputer. Retrieved from http://ejournal.stmikdumai.ac.id/index.php/ path/article/view/53

Dahlan, M. (2013). Membuat Web PHP. (Irma \& Eti, Eds.). Yogyakarta: CV. Mitra Utama.

Indrajani. (2015). Database Design. Jakarta: PT. Elex Media Komputindo.

Mustaqbal, M. S., Firdaus, R. F., \& Rahmadi, H. (2015). Pengujian Aplikasi Menggunakan Black Box Testing Boundary Value Analysis ( Studi Kasus: Aplikasi Prediksi Kelulusan SNMPTN ). Jurnal Ilmiah Teknologi Informasi Terapan, I(3), 31-36.

Noor, A. (2016). Aplikasi Kisah 25 Nabi dan Rasul Berbasis Android. Jurnal Sains \& Informatika, 2(2), 76-82. Retrieved from http://jurnal.politala.ac.id/index.php/JSI/arti cle/download/130/107

Nur Rubiati. (2018). Aplikasi Informasi Pelayanan Fitness Pada Golden Fitness Center Dumai Dengan Bahasa Pemrograman PHP. Jurnal Informatika, Manajemen Dan Komputer, 10(1), 1-6. Retrieved from http://ejournal.stmikdumai.ac.id/index.php/ path/article/view/53

Pascapraharastyan, R. A., Supriyanto, A., \& Sudarmaningtyas, P. (2014). Rancang Bangun Sistem Informasi Manajemen Arsip Rumah Sakit Bedah Surabaya Berbasis Web. Sistem Informasi, 3(1), 139143.

Prawono, J. A., \& Pamungkas, A. R. (2015). Sistem Informasi Pengelolaan Surat Masuk dan Surat Keluar Di Stmik Aub Surakarta. Jurnal Informatika, 2(1), 26-33.

Priyanti, D., \& Iriani, S. (2013). Sistem Informasi Data Penduduk Pada Desa Bogoharjo Kecamatan Ngadirojo Kabupaten Pacitan, 2(4), 55-61.

Rahmah, D. L. (2014). Perancangan Aplikasi Sistem Persuratan Berbasis Web Pada Pt .
Dwi Pilar Pratama, 7(3), 282-292.

Sutabri, T. (2012). Analisis Sistem Informasi. Yogyakarta. 